Brit. J. vener. Dis. (1962), 38, 69.

\title{
TRIAL OF ABOB (VIRUGON-BAYER) IN THE TREATMENT OF NON-GONOCOCCAL URETHRITIS*
}

BY

R. W. LLOYD-DAVIES

Lydia Department, St. Thomas' Hospital, London

The treatment of non-gonococcal urethritis (NGU) is empirical, and so far, no completely satisfactory therapeutic agent has been found. The aetiology of NGU is not fully understood, but it appears possible that a virus may play some part in its causation. Inclusion bodies were first demonstrated in cells in urethral smears in cases of NGU by Lindner (1910). Other workers, including Harkness (1945) in England and Siboulet (1955) in France, have also reported the presence of inclusion bodies.

A laboratory trial of the substance $\mathrm{N}^{\prime} \cdot \mathrm{N}^{\prime}$-anhydrobis (B hydroxyethyl) biguanide $\mathrm{HCl}$ (ABOB), the chemical composition of which is shown in the Figure, caused suppression of viral multiplication of Influenza Strain A in the chick embryo in vivo (Liu and Engle, 1960), and clinical trials in the Scandinavian influenza epidemic during the winter of 1960 led to favourable reports on the prophylaxis and treatment of influenza and other viral infections with this agent.

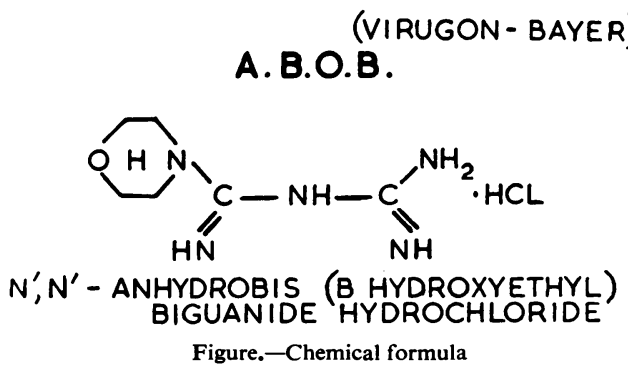

The purpose of the trial reported below was to assess the place of $\mathrm{ABOB}$ in the treatment of NGU.

\section{Material}

Three trials involving a total of 100 patients were carried out with different dosage schedules.

TRIal I: Patients were selected irrespective of race but excluding those who had had urethritis within 3 months of the trial, and those found to have Trichomonas vaginalis.

* Short paper read to the M.S.S.V.D. on November 24, 1961.
Fifty male patients were given either sixty $100-\mathrm{mg}$. tablets ABOB (200 mg. three times daily for 10 days) or a similar number of placebo tablets by a double-blind method.

TRIAL II : 25 white male patients were selected with no past history of urethritis. They were given twenty $200-\mathrm{mg}$. tablets ABOB ( $400 \mathrm{mg}$. twice daily for 10 days).

TrIAL III: 25 white male patients were selected as for Trial II and given thirty $400-\mathrm{mg}$. tablets ABOB (400 mg. three times daily for 10 days).

It had been intended that the female sex contacts of these patients should be similarly treated, but so few attended that this plan was abandoned. The females who did attend were treated in the routine way with $1 \mathrm{~g}$. streptomycin and a sulphonamide (Midicel) $0.5 \mathrm{~g}$. daily for 5 days.

TRIAL IV: For comparison with the patients in the trial series, the notes of fifty white male patients, with no past history of urethritis and treated routinely with streptomycin and sulphonamide, were examined and the cure rate assessed. A further ten patients, selected as in the second trial, who had been treated with streptomycin and sulphonamide, had an early morning smear taken 14 days after treatment had been started. These were included, because some of the trial patients, although virtually asymptomatic, were considered as failures on the findings of an early morning smear taken at that stage.

\section{Method}

Diagnosis.-NGU was diagnosed by the examination of a urethral smear. A wet preparation and culture for Trichomonas vaginalis were then taken and also blood for serological tests for syphilis. The findings of the two-glass urine test were also recorded.

Treatment.-Contact slips were given to each patient. Packets containing the tablets were handed out, labelled only with a number and instructions for taking the drug. The normal instructions banning alcohol and sexual intercourse were given routinely.

Follow-up.-Each patient was then seen at 1 and 2 weeks after the start of treatment, and on each occasion the findings of the two-glass test were recorded. When a frank urethral discharge was found at the 2 weeks' stage, or the symptoms or the results of the two glass test indicated the need for an early morning smear, this was then 
arranged; if more than scanty pus cells were found in the smear, the patient was regarded as a treatment failure and was then re-treated with streptomycin and sulphonamide.

At the end of the 3 rd or 4 th week, prostatic massage was performed provided no evidence of urethritis could be found. Trichomonal infection was again excluded and any patient with prostatitis was treated appropriately. Patients were then seen at 2 to 4-week intervals for up to 3 months after treatment, when a further prostatic massage was carried out as a test of cure, and the second series of serological tests for syphilis was done. Providing these were all satisfactory, the patient was then discharged. The two-glass test was carried out and recorded at each attendance.

\section{Results}

Table I shows the results of all trials.

In the double-blind trial, only five patients were discharged as cured, two in the ABOB group and three in the placebo group. Sixteen patients defaulted, seven before the first prostatic massage (early) and nine after that stage (late). Even if these defaulters could all be regarded as cured, the cure rate for $A B O B$ would be only 41 per cent. and that for the placebo 48 per cent. Both these figures are less than might be expected for an untreated series and, if the defaulters are excluded, the figures are 13 and 19 per cent. respectively.

The results in the second group on the intermediate dosage are shown in Table I. Excluding the seven defaulters, 22 per cent. were discharged as cured, or 44 per cent. if the defaulters are included.

The results in the third group on the highest dosage are given in Table I; 50 per cent. were discharged as cured, 63 per cent. if defaulters are included. It will be noted that even these latter figures are still within the range of cure for an untreated series.

The group of fifty patients treated routinely with streptomycin and sulphonamide (Table I) had a cure rate of 73 per cent., which agrees well with the results of other trials.
The group of ten patients from whom an early morning smear was taken 14 days after treatment with streptomycin and sulphonamide showed that three (30 per cent.) had an early morning discharge, though on being questioned they said they had been asymptomatic. Although this group is small, it is suggested that this is a high figure when it is generally recognized that 75 to 80 per cent. of patients will be cured with streptomycin and sulphonamide.

\section{Discussion}

The value of $\mathrm{ABOB}$ as an anti-viral agent is still not fully assessed. Liu and Engle (1960) suggested that it was virostatic and thought that it probably inhibited the entire replication process of the intracellular influenza strain A virus in the cells of the chick embryo. Melander (1960a), working with a similar strain of virus, found that $\mathrm{ABOB}$, particularly in combination with the xerostomia-producing drugs (anticholinergic drugs which induce dryness of mucosal surfaces), minimized the degree of consolidation in mouse lungs. Melander (1960b) also investigated the pharmacological properties of $\mathrm{ABOB}$ and found a low toxicity and favourable absorption and excretion rate in both animals and man. The lack of toxicity has been emphasized throughout the literature, and has been borne out by my own experience. The few side-effects reported, mostly mild gastro-intestinal symptoms, seem to be related more to the conditions treated and to the combination with xerostomia-producing drugs, than to ABOB itself. The work particularly of Sandahl and Sjöberg (1960) and of Bohmansson (1960) suggested that the drug had a prophylactic value in influenza, and Farquhar (1960) reported some protection against measles, both in animal experiments and in children. Stenkula (1959) found that patients suffering from influenza appeared to get better more quickly when treated with $\mathrm{ABOB}$ than did controls,

TABLE I

RESULTS IN FOUR TREATMENT TRIALS

\begin{tabular}{|c|c|c|c|c|c|c|c|c|c|}
\hline \multirow[b]{2}{*}{ Trial No. } & \multirow{2}{*}{\multicolumn{2}{|c|}{ Drug }} & \multirow[b]{2}{*}{ Dosage } & \multirow[b]{2}{*}{ No. of Patients } & \multicolumn{5}{|c|}{ Results } \\
\hline & & & & & $\begin{array}{c}\text { Discharged } \\
\text { as } \\
\text { Cured }\end{array}$ & $\begin{array}{l}\text { Treatment } \\
\text { Failure }\end{array}$ & Defaulted & $\begin{array}{c}\text { Excluded } \\
\text { from } \\
\text { Trial }\end{array}$ & $\begin{array}{l}\text { Cure Rate } \\
\text { (per cent.) }\end{array}$ \\
\hline \multirow[t]{2}{*}{$\mathbf{I}$} & $\underset{\text { Placebo }}{\text { ABOB.. }}$ & $\therefore$ & $\begin{array}{c}200 \mathrm{mg} . \\
\text { three times a day }\end{array}$ & $\begin{array}{l}25 \\
25\end{array}$ & 2 & $\begin{array}{l}13 \\
13\end{array}$ & $\begin{array}{l}7 \\
9\end{array}$ & $\begin{array}{l}3 \\
0\end{array}$ & \multirow[t]{2}{*}{$\begin{array}{l}13 \\
19\end{array}$} \\
\hline & Total .. & . & & 50 & 5 & 26 & 16 & 3 & \\
\hline II & ABOB... & . & $\begin{array}{l}400 \text { mg. } \\
\text { twice daily }\end{array}$ & 25 & 4 & 14 & 7 & $\mathbf{0}$ & 22 \\
\hline III & ABOB & .. & $\begin{array}{l}400 \mathrm{mg} . \\
\text { three times a day }\end{array}$ & 25 & 8 & 8 & 6 & 3 & 50 \\
\hline IV & \multicolumn{3}{|c|}{ Streptomycin + Sulphonamide } & 50 & 19 & 7 & 24 & 0 & 73 \\
\hline
\end{tabular}


but such evidence can be misleading and recent observations on the placebo effect (British Medical Journal, 1961) may be relevant. The drug has also been tried in various herpetic conditions but the results are difficult to assess.

Bateson (1960), on the other hand, reported no reduction in the incidence of upper respiratory infection in patients in an industrial firm, although only a low dosage was employed, and Watson (1960) found no effect on the course of thirty influenza-like infections. However, it would seem that there may be a place for this drug in the treatment of viral infections.

It is known that approximately 60 per cent. of cases of NGU will subside spontaneously if the patient is given a placebo or left untreated over 8 weeks (Gartman and Leibovitz, 1955). Jelinek (1957) quoted a series of percentage rates of cure, those for streptomycin and sulphonamide and for the tetracycline group being approximately 80 per cent. In order to show a definite improvement with therapy, a percentage cure rate of over 85 per cent. would be necessary, and this has not been achieved in the trial under review (Table I), but the streptomycin and sulphonamide series showed a cure rate of 73 per cent., which is comparable with the figures quoted by Jelinek (Table II).

TABLE II

CURE RATES (PER CENT.) WITH STANDARD TREATMENT

\begin{tabular}{|c|c|c|c|}
\hline Series & Source & & $\begin{array}{l}\text { Cure Rate } \\
\text { (per cent.) }\end{array}$ \\
\hline Controls & Gartman and Leibovitz & & $58 \cdot 5$ \\
\hline \multirow{2}{*}{$\begin{array}{l}\text { Streptomycin } \\
\text { and } \\
\text { Sulphonamide }\end{array}$} & St. Thomas' Hospital . & $\ldots$ & 73 \\
\hline & $\begin{array}{lll}\text { Jelinek (1957) } & \ldots\end{array}$ & . & 80 \\
\hline Tetracyclines & Jelinek (1957) $\quad .$. & .. & 78 \\
\hline
\end{tabular}

It may be noted that among the failures in this trial, twelve patients were assessed by means of an early morning smear a fortnight after starting treatment. Pus was found in the smears of a small number of asymptomatic patients treated with streptomycin and sulphonamide. This may help to explain why the cure rates were below those expected in an untreated series, as 2 weeks is probably too early to assess this condition.

\section{Summary}

In a trial of the anti-viral substance $\mathrm{ABOB}$ in 75 cases of non-gonococcal urethritis the cure rate showed no improvement over the usual spontaneous cure rate. It is concluded that, in the dosages used in this trial, there is no place for $\mathrm{ABOB}$ in the treatment of NGU.

I should like to thank Dr. C. S. Nicol for his help and encouragement without which this study could not have been carried out, and also the medical officers and other staff of the department for their co-operation.

I am indebted to Dr. K. Boheimer of Bayer Products for the supplies of $\mathrm{ABOB}$ and placebo tablets, to $\mathrm{Mr}$. M. S. Rigden, F.C.A., for his statistical help and to Miss R. Grau for the secretarial work.

\section{REFERENCES}

Bateson, P. R. (1960). Symposium ABOB, Stockholm, Oct. 28.

Bohmansson, G. (1960). Symposium ABOB, Stockholm, Oct. 28.

British Medical Journal (1961). Annotation: Placebos, 1, 43.

Farquhar, J. (1960). Symposium ABOB, Stockholm, Oct. 28.

Gartman, E., and Leibovitz, A. (1955). Brit.J. vener. Dis., 31, 92.

Harkness, A. H. (1945). Ibid., $21,93$.

(1950). "Non-gonococcal Urethritis", p. 67. Livingstone, Edinburgh.

Jelinek, G. (1957). Brit. J. vener. Dis., 33, 156.

Lindner, K. (1910). Wien. klin. Wschr., 23, 283.

Liu, O. C., and Engle, C. G. (1960). Symposium ABOB, Stockholm, Oct. 28.

Melander, B. (1960a). Antibiot. and Chemother., 10, 34. (1960b). Toxicol. appl. Pharmacol., 2, 474.

Sandahl, C., and Sjöberg, M. (1960). Symposium ABOB, Stockholm, Oct. 28.

Siboulet, A. (1955). Brit. J. vener. Dis., 31, 235.

Stenkula, F. (1959). Fortschr. Med., $77,318$.

Watson, G. I. (1960). Brit. med. J., 2, 1785.

Essai de l'ABOB (Virugon-Bayer) dans le traitement de l'urétrite non-gonococcique

\section{RÉSUMÉ}

Au cours d'un essai du virulicide $\mathrm{ABOB}$ dans 75 cas d'urétrite non-gonococcique, le taux de guérisons obtenues ne fut pas plus élevé que celui des guérisons spontanées. On conclut que l'ABOB n'a aucune place dans la thérapie de l'urétrite non-gonococcique dans les dosages employés dans cet essai. 